
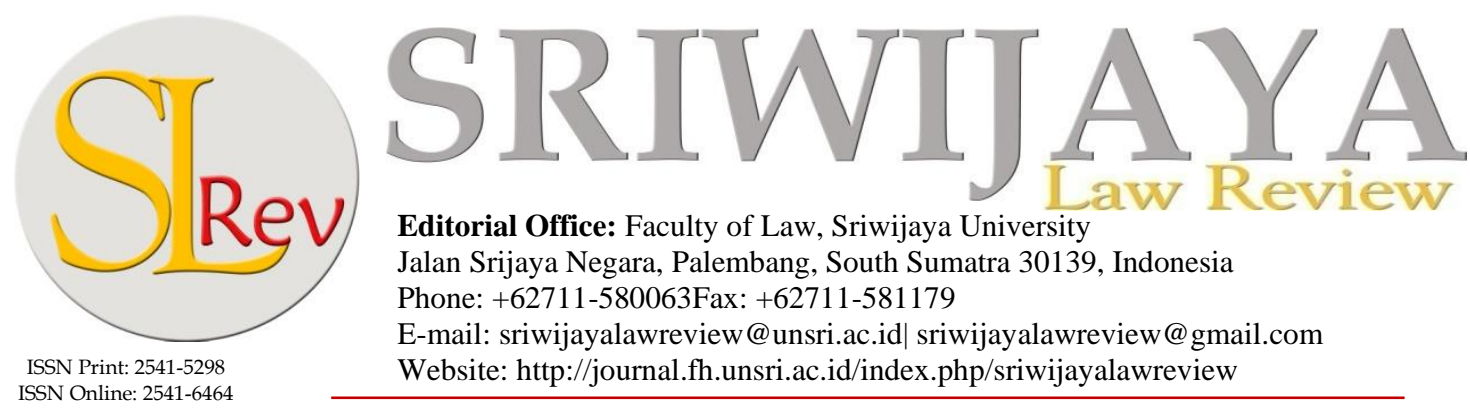

Editorial Office: Faculty of Law, Sriwijaya University

Jalan Srijaya Negara, Palembang, South Sumatra 30139, Indonesia

Phone: +62711-580063Fax: +62711-581179

E-mail: sriwijayalawreview@unsri.ac.id| sriwijayalawreview@gmail.com

Website: http://journal.fh.unsri.ac.id/index.php/sriwijayalawreview

\title{
The Problematics of Management Personal Protection Equipment Waste related to Covid-19 in Indonesia
}

\author{
Muhammad Hadin Muhjad, ${ }^{\mathrm{a}^{*}}$ Fakhruddin Razy, ${ }^{\mathrm{b}}$ and Ahmad Fikri Hadin ${ }^{\mathrm{a}}$ \\ * Corresponding Author. Faculty of Law, University of Lambung Mangkurat, Banjarmasin, Indonesia. Email: mhmu- \\ hjad@ulm.ac.id \\ b Faculty of Humanities, University of Sari Mulia, Indonesia. Email: razyf1463@gmail.com
}

\begin{tabular}{|c|c|}
\hline Article & Abstract \\
\hline $\begin{array}{l}\text { Keywords: } \\
\text { B3 Waste; Covid-19; } \\
\text { Indonesian Law; Per- } \\
\text { sonal Protective Equip- } \\
\text { ment Management. } \\
\text { Article History } \\
\text { Received: Mar 3, 2021; } \\
\text { Reviewed: Jul 12, 2021; } \\
\text { Accepted: Jul 21, 2021; } \\
\text { Published: Jul 31, 2021. } \\
\text { DOI: } \\
\text { 10.28946/slrev.Vol5.Iss2. } \\
\text { 1161.pp300-308 }\end{array}$ & $\begin{array}{l}\text { Medical Waste for Covid-19 Personal Protective Equipment (PPE) is classified } \\
\text { as B3, which can potentially be a medium for spreading the virus. Therefore, } \\
\text { management must be carried out, consisting of collection, sorting, transportation, } \\
\text { temporary storage, to processing (destruction) based on the Circular of the Minis- } \\
\text { ter of Environment and Forestry Number } 2 \text { of } 2020 \text { using the incinerator and } \\
\text { problematic autoclave methods. The purpose of this study is to find out how the } \\
\text { law regulates the management of Covid-19 PPE waste in Indonesia and how it } \\
\text { should be. The research method used is normative legal research. The results } \\
\text { showed that based on the Circular Letter of the Minister of LHK No. } 2 \text { of } 2020 \text {, it } \\
\text { is determined that the destruction of Covid-19 PPE waste as B3 waste must go } \\
\text { through an incinerator facility with a minimum combustion temperature of } 800^{\circ} \\
\mathrm{C} \text { and an autoclave equipped with a shredder. This method is considered overkill } \\
\text { and incurs high costs. The conclusion of this study is to provide input for the } \\
\text { Government to review or revise the Circular regarding safer Covid-19 PPE B3 } \\
\text { waste management, including through the pyrolysis method. }\end{array}$ \\
\hline
\end{tabular}

(C)2021; This is an Open Access Research distributed under the term of the Creative Commons Attribution License (https://Creativecommons.org/licences/by/4.0), which permits unrestricted use, distribution, and reproduction in any medium, provided the original works is properly cited.

\section{INTRODUCTION}

This pandemic period is an undeniable fact that there is a lot of waste or garbage originating from Covid-19 PPE that is not appropriately managed. Covid-19 Waste includes Hazardous and Toxic (B3) waste, so according to the Government Regulation of the Republic of Indonesia Number 22 of 2021 concerning Environmental Protection and Management, this B3 waste is dangerous and needs to be managed by the Government.

It is mandatory to use Personal Protective Equipment (PPE) in a pandemic situation. Most of the basic PPE materials are used for single use. The large quantity is resulting in a drastic pile of Medical Waste. Moreover, it has the potential to be mixed with other household waste, which can endanger waste transport officers who generally work without PPE or use inadequate PPE. 
The numbers are worrying for medical waste piles around the world, for example, in Hubei, China, which previously went from 40 tons/day to 240 tons per day. Meanwhile, in Jakarta, it is estimated that medical waste is 212 tons/day. In addition, only 110 of the 2,889 hospitals with a licensed incinerator in medical waste management operations. ${ }^{1}$

The handling of infectious waste or medical B3 specifically for Covid-19 is specifically regulated in the Circular Letter of the Minister of Environment and Forestry Number: SE.2/MENLHK/PSLB3/PLB.3/3/2020. This rule concerns the Management of Infectious Waste (B3 Waste) and Household Waste from Handling Corona Virus Disease (Covid-19). Broadly speaking, this regulation regulates the management of infectious waste originating from health facilities for storage in sealed packaging for a maximum of 2 days from the time it is produced; transport and/or destroy in LB3 processing using an incinerator facility with a minimum combustion temperature of $800^{\circ} \mathrm{C}$ or an autoclave equipped with a chopper.

Basically, the regulations mentioned above apply to the public and public places, meaning not only those in hospitals. Considering that B3 waste in hospitals is very worrying to patients, so this matter must be regulated. Also, because Covid-19 PPE Waste is classified as B3 based on Law concerning Environmental Protection and Management, it must be completed with permits starting from temporary placement, collection, transportation and processing of B3. Indeed, the legal power of the Circular Letter of the Minister of Environment and Forestry is not too strong. It is because from the point of view of Administrative Law as the basis for policy regulations that follow up on the authority of the Minister of the Environment to issue permits in B3 Waste management based on Article 59 paragraph (4) of Law no. 32 of 2009 concerning Environmental Protection and Management Jo. Attachment of Law no. 23 of 2014 concerning Regional Government jo. PP No. 22 Year 2021. ${ }^{2}$ The goal is not to realise the mandate of Law Number 36 of 2009 concerning Health in Article 163 concerning Environmental Health which contains environmental health efforts aimed at realising a healthy quality of the environment, whether physical, chemical, biological, or social, that allows everyone to achieve a healthy level of health.

The Director-General of Waste, Waste and B3 Management (PSLB3) of the Ministry of Environment and Forestry (KLHK) stated that there had been an increase in the volume of medical Waste in Indonesia, which ranges from 30 to 50 per cent. As of October 15, 2020, there were 1,662.75 tons of medical waste due to Covid-19. Another study estimates that as many as 159,214,791 disposable masks are used daily by around $273,753,080$ residents in Indonesia. ${ }^{3}$

B3 PPE Covid-19 waste management, which must be destroyed, is the same as other B3 medical waste through incinerator based on a permit issued by the Minister of Environment and Forestry, while not all hospitals have such incinerator, for example in South Kalimantan Province, which has a hospital. As many as 26 units, there are only four hospitals that have incinerators. In addition to technical issues, it turns out that the management of Covid-19 B3 Waste in the form of destruction carried out with an incinerator is not a recommended method because it can pose a health risk if it is carried out by burning but must be done by evaporation.

\footnotetext{
Teddy Prasetiawan, "Permasalahan Limbah Medis Covid-19 Di Indonesia," Pusat Penelitian Badan Keahlian DPR RI XII, no. 9 (2020).

2 "The Law Number 32 of 2009 on Environmental Protection and Management" (n.d.).

3 "LKHK Catat Paningkatan 30-50 Persen Limbah Medis Saat Pandemi," Anataranews.Com, November 2020, https://www.antaranews.com/berita/1837616/klhk-catat-peningkatan-30-50-persen-limbah-medis-saat-pandemi.
} 
Based on research, improper management of Covid-19 PPE waste can cause environmental problems that have the potential to transmit the Covid-19 virus to patients, health workers, and waste managers. In addition, open burning and disposal of the medical waste directly into the environment without going through a treatment process can affect air quality and potentially impact human health due to the toxins produced. Environmental legal conditions have not fully accommodated related to waste management as contained in Law Number 36 of 2009 concerning Health Article 163. It contains environmental health efforts to realise a healthy environmental quality, both physical, chemical, biological, and social, that enable everyone to achieve the highest degree of health.

Therefore, regulations governing the management of Covid-19 PPE waste need to be studied in depth from the health law aspect. Based on this background, this research is focused on finding out how the law regulates the management of Covid-19 PPE waste in Indonesia.

\section{RESEARCH METHODS}

The research method used is qualitative research with a normative legal approach or doctrinal research, coming to a tentative conclusion. ${ }^{4}$ Because the legal study on the management of the Covid19 B3 Waste carried out a juridical analysis of the regulations governing the management of the Covid-19 B3 Waste, then the norms contained in the regulation were analysed scientifically according to the study of experts in their respective fields regarding the management of the Covid-19 PPE B3 Waste. Furthermore, conclusions were drawn on the accuracy of the norms governing the management of Covid-19 B3 Waste based on the Health Law. In problem-solving, this article uses two approaches. The statutory approach is used to see if the basic rules are inconsistent with technical rules in the management of Covid-19 B3 Waste. The case approach used in cases of destruction comes from the point of view of the environmental health law. It is not a recommended method because it can pose a health risk if it is carried out by burning.

\section{ANALYSIS AND DISCUSSION}

\section{Legal Basis for Medical B3 Waste Management}

The legal basis for B3 Waste Management is Article 59 paragraph (4) of Law no. 32 of 2009 clearly and unequivocally states: "B3 waste management must obtain a permit from the Minister, governor or regents/mayors following their authority." Due to the hazardous nature of B3 waste and risks to humans and the environment, the management of B3 waste must be carried out with a precautionary principle approach through the application of licensing instruments, ranging from storage, collection and transportation to its utilisation and management and even it's landfilling must be properly regulated. From a legal point of view, there is a difference between the management of B3 Waste and non-B3 Waste, which lies in the matter of legal liability. In non-B3 waste, the final result of management is more important than how to achieve that result. However, in addition to B3 waste and the final product, both technical and non-technical management methods must also comply with applicable regulations.

4 Terry Hutchinson, Researching and Writing in Law (Pyrmont, NSW, 2002). 
The permits required for B3 waste management based on Government Regulation Number 101 of 2014 include B3 waste temporary storage permits, ${ }^{5}$ B3 waste collection permits, B3 waste utilisation permits, B3 waste processing and/or landfill permits, B3 waste transport permits. The permit is regulated in more detail in law No. P.95/MenLHK/Setjen/KUM.1/11/2018. However, based on the latest Job Creation Law and Government Regulation Number 22 of 2021, it regulates changes to the nomenclature from the B3 Waste Management Permit to a Technical Approval in the B3 Waste Management Sector, which is the basis for the latest B3 waste management permit. The purpose of B-3 waste management is to prevent, overcome environmental pollution or damage caused by B-3 waste and restore the quality of the environment that has been polluted so that it is not suitable for its normal function. ${ }^{6}$

\section{The Problems of PPE Waste Management Related to Covid-19}

In Indonesia, the handling of infectious waste or medical B3 specifically for Covid-19 is specifically regulated in the Circular Letter of the Minister of Environment and Forestry Number: SE.2/MENLHK/PSLB3/PLB.3/3/2020. This rule concerns the Management of Infectious Waste and Household Waste from Handling Corona Virus Disease (Covid-19).

Policies for managing B3 waste generated from hospitals involve various parties adjusted to its management stage. The Government plays a role in policymaking, regulation, licensing, providing guidance, inspection, assessment and facilitating activities related to the development and infrastructure of B3 waste management facilities from health service facilities. Likewise, local governments are also expected to assist in implementing the B3 waste management system as a whole. Meanwhile, as a producer of B3 waste, the hospital is obliged to understand and comply with the procedures and requirements to carry out its waste management obligations, likewise, with the parties related to B3 waste management who are partners of health providers. ${ }^{7}$

One way of managing hospital PPE waste in Indonesia is using an incinerator. In Indonesia, out of a total of 2,889 Hospitals, only 82 Hospitals have licensed incinerators. Several hospitals in Indonesia do not have incinerators, so the hospital contracts private waste management services, which is recorded that $92 \%$ of them are located on the island of Java. The long-distance from the hospital to the medical waste disposal site can increase the risk of illegal waste disposal and disease transmission. ${ }^{8}$

During the Covid-19 pandemic, a significant increase in medical waste in health facilities was around 30-50\%. The Association of Indonesian Hospitals (PERSI) estimates that the total medical waste generated during the Covid-19 pandemic in health facilities, such as hospitals, health centres, pharmacies, maternity hospitals, and polyclinics, is 296.86 tonnes/day. In addition, data from the Ministry of Environment and Forestry collected from 34 provinces in Indonesia also shows that med-

5 Alvionita Ajeng Purwanti, "The Processing of Hazardous and Toxic Hospital Solid Waste In Dr. Soetomo Hospital Surabaya,” Jurnal Kesehatan Lingkungan 10, no. 3 (2018), https://e-journal.unair.ac.id/ JKL/article/view/6721.

6 Tentrami Hayuning Ichtiakhiri and Sudarmaji, "Pengelolaan Limbah B3 Dan Keluhan Kesehatan Pekerja Di PT. Inka (Persero) Kota Madiun,” Jurnal Kesehatan Lingkungan 8, no. 1 (2015): 118-27, https://ejournal.unair.ac.id/JKL/article/viewFile/3109/2260.

7 Absori and Muhamad Latif, "Kebijakan Hukum Dalam Pengelolaan Limbah Bahan Berbahaya Dan Beracun (B3): Studi Implementasi Pengelolaan Limbah Medis Di Rumah Sakit Salatiga,” Journal of Indonesian Law 1, no. 1 (2020): 91-117, https://e-journal.iainsalatiga.ac.id/index.php/jil/article/view/4381.

8 Prasetiawan, "Permasalahan Limbah Medis Covid-19 Di Indonesia." 
ical waste in health facilities continues to increase, with a total of 1,662.75 tons of Covid-19 Waste until October $152020 .^{9}$ Indonesia's health service facilities are 2,889 hospitals, 20,062 health centres, 7,641 clinics, and other service facilities such as health laboratories and pharmacies. Based on these data, it is estimated that the medical waste produced in Indonesia will reach 294.66 tons where the medical waste processing capacity only reaches 53.12 tons/day, or it can be said that there will be a deficit in the amount of medical waste as much as 70,432 tons/day.

Seriousness is awaited with the increasing number of Covid-19 in Indonesia. Research has shown that the virus can survive certain conditions of temperature and humidity. However, with the disinfection process, the virus will be easy to inactivate or, in other words, not be contagious.

As medical B3 waste, it is the Government's responsibility so that health facilities can focus on treating patients. If attention is paid to the front side for patient care in hospital management, it is essential as the backside (waste disposal). So, the front part of BPJS, billing and the back is about waste so that the service function is not disturbed. The waste disposal function must also be prioritised so that the hospital's primary function is to provide services running smoothly. ${ }^{10}$

Handling of infectious waste originating from service facilities such as hospitals is carried out by handling infectious waste. The procedures are as follows: 1) B3 medical waste in solid form is put into a container lined with a yellow plastic bag with the symbol "biohazard"; 2) storing infectious waste in a closed package for a maximum of two days from the time it is produced; 3) transporting and/or destroying B3 waste, through an incinerator with a minimum combustion temperature of 800 $\mathrm{C}$, or using an autoclave equipped with a shredder. The residue resulting from combustion or shredded autoclave is packaged and attached with a "toxic" symbol and a B3 waste label which is then stored in the Temporary Hazardous Waste Storage Place for subsequent delivery to the B3 waste manager. ${ }^{11}$

The Decree of the Minister of Health of the Republic of Indonesia Number HK 01.07 also regulates the Management of Hazardous and Toxic Waste (B3) Medical Solids in Health Service Facilities for Handling Covid-19. The B3 waste is packed and tightly tied, disinfected after the container for disposing of the waste is complete or at most twelve hours. Meanwhile, Medical B3 Solid waste must be transported, recorded and stored in a B3 Waste Temporary Storage (TPS) for a maximum of 24 hours or a special place.

Government Regulation No. 22/2021 on Hazardous and Toxic Waste Management regulates waste management from stipulation to disposal. Infectious clinical and expired pharmaceutical wastes are classified as hazardous waste categories. Regulation of the Minister of Environment and Forestry Number P 56 of 2015 concerning Procedures and Technical Requirements for the Management of B3 Waste from the Health Care Facilities has regulated the technical aspects of storing, transporting, processing, burying and landfilling B3 waste at the Health Centre. ${ }^{12}$

9 Prasetiawan.

10 Elsa Yolarita and Desi Widia Kusuma, "Pengelolaan Limbah B3 Medis Rumah Sakit Di Sumatera Barat Pada Masa Pandemi Covid-19," Jurnal Ekologi Kesehatan 19, no. 3 (2020): 148-60.

11 Pricillia Putri Ervian Sitompul, "Menilik Kebijakan Pengolahan Limbah B3 Fasilitas Pelayanan Kesehatan Selama Pandemi COVID-19 Di Provinsi Jawa Barat," Dinamika Lingkungan Indonesia 8, no. 1 (2021), https://dli.ejournal.unri.ac.id/index.php/DL.

12 Sadia Ilyas, Rajiv Ranjan Srivastava, and Hyunjung Kim, "Disinfection Technology and Strategies for Covid-19 Hospital and Bio-Medical Waste Management,” Elsevier, 2020, 1-12, 10.1016/j.scitotenv.2020.141652. 
The handling of infectious waste or medical B3 specifically for Covid-19 is specifically regulated (SE Minister of LHK No. 2 of 2020). This rule concerns the Management of Infectious Waste (B3 Waste) and Household Waste from Handling Corona Virus Disease (Covid-19). This regulation regulates the management of infectious waste originating from health facilities for storage in secure packaging for a maximum of 2 days from the time it is produced, transport and/or destroys in LB3 processing using an incinerator facility with a minimum combustion temperature of $800^{\circ} \mathrm{C}$ or an autoclave equipped with a chopper.

Based on the Decree of the Minister of LHK No. SK.361/Menlhk/Setjen/Plb.3/8/2017 concerning Permits for Management of Hazardous and Toxic Waste on behalf of the Regional Public Service Agency. An example of a case is the Balangan Regional General Hospital, South Kalimantan Province, where the Minister of LHK has issued an Incinerator Operational Permit Number: 445/001/BLUD-RSUD-BLG/2017 dated February 10, 2017. The B3 Management Permit at the Balangan Regional General Hospital has determined Procedures and Technical Requirements for Storage and Collection of Hazardous and Toxic Waste.

Based on the regulation, it is clear that the destruction of B3 waste by burning through an incinerator states that infectious waste originating from health care facilities is stored in secure packaging for a maximum of 2 (two) days from the time it is produced. Transportation and/or destruction of waste treatment plants: 1) Incinerator facilities through combustion at a minimum temperature of $800^{\circ} \mathrm{C}$; and 2) The autoclave is equipped with an enumerator, which is then stored in the B3 Waste Temporary Storage for further delivery to the B3 Waste manager.

There are six steps to manage B3 Waste or medical Waste based on the Regulation of the Minister of Environment and Forestry Number P-56 of 2015. The six steps are reduction and sorting, collection and storage, transportation, processing, burial, and stockpiling. Suppose it turns out that B3 waste management does not have a permit as required in Law Number 32 of 2009 concerning Environmental Protection and Management. In that case, if a business entity/activity intentionally disposes of B3 waste into environmental media without a permit, a warning will be issued until the business license is issued. This administrative sanction does not free the person in charge of the business from criminal entanglement. Whoever intentionally disposes of B3 waste to harm others is threatened with imprisonment and a fine.

Regarding Covid-19 PPE waste, by paying attention to the treatment of PPE Covid-19 waste carried out in hospitals or third-parties as above by burning through an incinerator, it turns out that it is not the right way to treat waste according to environmental health law. For medical Waste from Covid-19, there is no need to go through a burning process like this because the Covid-19 virus can die at a temperature of 100 degrees Celsius and after being on hard surfaces such as plastic and paper for 72 hours. ${ }^{13}$

Disposal of Medical Waste by burning incinerators is often a problem. It is because air emissions from these incinerators can pollute the air. Suppose they do not have reasonable air control. Besides that, the incinerator itself is still limited. It can also be against health laws. Technical regulations governing the disposal of medical waste should adopt technological developments that are safer for health.

13 Yuyun Yunia Ismawati, "Empat Cara Mengolah Lombah Masker \& APD Selama Pandemi Covid-19, Mana Yang Lebih Efektif?,” The Coversation, 2020, https://theconversation.com. 
In this regard, in 2003, WHO and UNEP, United Nations agencies that focus on environmental issues, legalised medical waste handling by the evaporation method autoclaving. The method serves as a substitute for the combustion method to prevent the release of persistent organic pollutants (POPs) or organic compounds that are toxic and last a long time in the environment. The autoclave method treats medical waste sterile by using hot steam, chopping it, and finally discharging it to the landfill. ${ }^{14}$

A simple experiment shows that surgical masks are difficult to get wet unless they are soaked for 24 hours. Also, hard to burn, and there are plastic elements. This mask is admittedly challenging to destroy. It is dangerous to throw it carelessly. So, to reduce infection, solid waste can be left for two days, then disposed of. Viruses can die at a temperature of 100 degrees, so if only to kill the virus, the incinerator is overkill. ${ }^{15}$ In addition, some studies are innovative in processing PPE waste, namely technology that uses the pyrolysis method to treat waste that will produce alternative fuels. Efforts to utilise this technology in processing PPE waste need to be considered one of the practical steps to reduce the accumulation of PPE waste due to the pandemic. They can be an innovation for the community if this technology is applied on a smaller and easily accessible scale. ${ }^{16}$

Pyrolysis technology is defined as a heating system without oxygen that converts plastic waste into fuel oil by returning the plastic to its original form, the principle of this pyrolysis technology is the conversion of plastic waste to fuel oil, where this process can return the plastic to its original shape. This pyrolysis technology can be used to overcome the accumulated waste of personal protective equipment at the time of the pandemic, where the building blocks of personal protective equipment are generally plastic. ${ }^{17}$ Therefore, legal products that have regulated the management of PPE waste as prevention of Covid-19 need to be reviewed with more environmentally friendly waste management through the application of innovative technology. One of them is through the application of the pyrolysis method.

\section{CONCLUSION}

Covid-19 PPE waste is classified as B3 waste because exceptional management is needed starting from the collection, temporary placement, transportation, stockpiling and destruction. Destruction is carried out using an incinerator based on a permit issued by the Minister of Environment and Forestry. Destruction of Covid-19 Waste, which is carried out with an incinerator from the point of view of Health law, is not the recommended method because it can pose a health risk if it is carried out by burning but must be carried out by evaporation or autoclaving or recycled by the Pyrolysis process. Thus, to protect the community against the dangers of PPE waste related to Covid-19 disease, it is necessary to review and clarify existing legal regulations regarding the management of PPE waste that is safe for humans and the environment. The technical regulations governing the destruction of

14 Luh De Suriyani, "Dampak Limbah Medis Saat Pandemi," Mongabay, 2020, https://www.mongabay.co.id/ 2020/10/05/dampak-limbah-medis-saat-pandemi/.

15 Syauki Isykapurnama, et.all, "Potensi Teknologi Pengolahan Berbasis Pirolisis Dalam Penanganan Limbah Alat Pelindung Diri Yang Menumpuk Di Masa Pandemi Covid-19," Journal of Research in Pharmacy 1, no. 1 (2021): 3439.

16 Basel Convention, Technical Guidelines on the Environmentally Sound Management of Biomedical and Healthcare Wastes (Y1; Y3) (UNEP, 2003).

17 Ismawati, "Empat Cara Mengolah Lombah Masker \& APD Selama Pandemi Covid-19, Mana Yang Lebih Efektif?" 
medical waste should adopt technological developments that are safer for health. Therefore, the government reviews or revises the Circular regarding safer Covid-19 PPE B3 waste management, including through the pyrolysis method.

\section{REFERENCES}

Ajeng, Alvionita Purwanti. "The Processing Of Hazardous And Toxic Hospital Solid Waste In Dr.Soetomo Hospital Surabaya" Jurnal Kesehatan Lingkungan Vol 10, No 3 (2018) https://ejournal.unair.ac.id/JKL/article/view/6721

Battista, Rosa Alessia MD; Ferraro, Milena MD; Piccioni, Lucia Oriella MD; Malzanni, Giulia Elvira MD; Bussi, Mario MD. "Personal Protective Equipment (PPE) in COVID 19 Pandemic Related Symptoms and Adverse Reactions in Healthcare Workers and General Population". Journal of Occupational and Environmental Medicine February 2021 Volume 63 Issue 2. https://journals.lww.com/joem/Fulltext/2021/02000/Personal_Protective_ Equipment_PPE_in_COVID_19.18.aspx

Convention, Basel. Technical Guidelines on the Environmentally Sound Management of Biomedical and Healthcare Wastes (Y1; Y3). UNEP, 2003.

Hutchinson, Terry. Researching and Writing in Law. Pyrmont, NSW, 2002.

Ilyas, Sadia, Rajiv Ranjan Srivastava, and Hyunjung Kim. "Disinfection Technology and Strategies for Covid-19 Hospital and Bio-Medical Waste Management." Elsevier, 2020, 1-12. 10.1016/j.scitotenv.2020.141652.

Ismawati, Yuyun Yunia. "Empat Cara Mengolah Lombah Masker \& APD Selama Pandemi Covid19, Mana Yang Lebih Efektif?" The Coversation, 2020. https://theconversation. com/empatcara-mengelola-limbah-masker-dan-apd-selama-pandemi-covid-19-mana-yang-lebih-efektif135956.

Isykapurnama, Syauki, Darsih Sarastri, and Hega 'Aisyah Mahardika. "Potensi Teknologi Pengolahan Berbasis Pirolisis Dalam Penanganan Limbah Alat Pelindung Diri Yang Menumpuk Di Masa Pandemi Covid-19." Journal of Research in Pharmacy 1, no. 1 (2021): 34-39. https://ejournal2.undip.ac.id/index.php/generics/article/view/9797.

Jumari, Arif. "Potensi Pelanggaran Pengelolaan Limbah Bahan Berbahaya dan Beracun" Jurnal Bestuur Vol.7, Issue.2, December, 2019 https://jurnal.uns.ac.id/bestuur/article/view/40414

Kusuma, Elsa Yolarita and Desi Widia. "Pengelolaan Limbah B3 Medis Rumah Sakit Di Sumatera Barat Pada Masa Pandemi Covid-19.” Jurnal Ekologi Kesehatan 19, no. 3 (2020): 148-60.

Latif, Absori and Muhamad. "Kebijakan Hukum Dalam Pengelolaan Limbah Bahan Berbahaya Dan Beracun (B3): Studi Implementasi Pengelolaan Limbah Medis Di Rumah Sakit Salatiga." Journal of Indonesian Law 1, no. 1 (2020): 91-117. https://e-journal.iainsalatiga. ac.id/index.php/jil/article/view/4381.

"LKHK Catat Paningkatan 30-50 Persen Limbah Medis Saat Pandemi." Anataranews.Com, November 2020. https://www.antaranews.com/berita/1837616/klhk-catat-peningkatan-30-50persen-limbah-medis-saat-pandemi.

Hermanto, Mohamad Oktama. "Urgensi Pengaturan Pengelolaan Limbah Masker Bekas Pakai Dalam Mencegah Penularan Covid-19." Jurnal Hukum Juni 2021. http://hukum. studentjournal.ub.ac.id/index.php/hukum/article/view/4337

Prasetiawan, Teddy. "Permasalahan Limbah Medis Covid-19 Di Indonesia." Pusat Penelitian Badan 
Keahlian DPR RI XII, no. 9 (2020).

Prihartanto. "Prediction of medical, hazardous waste generation from covid-19 patient handling hospitals". Jurnal Sains dan Teknologi Mitigasi Bencana, Vol. 15, No. 1, Juni 2020. https://ejurnal.bppt.go.id/index.php/JSTMB/article/view/4406

Putri, Pricillia Ervian Sitompul. "Menilik kebijakan pengolahan limbah B3 fasilitas pelayanan kesehatan selama pandemi COVID-19 di Provinsi Jawa Barat". Dinamika Lingkungan Indonesia, Januari 2021. Volume 8, Nomor 1. https://dli.ejournal.unri.ac.id/index.php/DL

Ramadhanty, Nia Purwanto, Syauqi Al Amin, Ainun Mardiyah, Yosia Retno Wahyuningtyas, "Pengaturan Pengelolaan Limbah Medis Covid-19" Jurnal Yustika Vol. 23 No. 02, Des 2020 http://journal.ubaya.ac.id/index.php/yustika

Rhiti and Y. Sri Pudyatmoko. "Kebijakan Perizinan Lingkungan Hidup Di Daerah Istimewa Yogyakarta". Mimbar Hukum Volume 28, Nomor 2, Juni 2016, https://jurnal.ugm. ac.id/jmh/issue/view/2210

Sudarmaji, Tentrami Hayuning Ichtiakhiri and. "Pengelolaan Limbah B3 Dan Keluhan Kesehatan Pekerja Di PT. Inka (Persero) Kota Madiun.” Jurnal Kesehatan Lingkungan 8, no. 1 (2015): 118-27. https://e-journal.unair.ac.id/JKL/article/viewFile/3109/2260.

Suriyani, Luh De. "Dampak Limbah Medis Saat Pandemi." Mongabay. 2020. https://www.mongabay.co.id/2020/10/05/dampak-limbah-medis-saat-pandemi/.

Sutrisno, Hendry and Fitriana Meilasari. "Review: Medical Waste Management For Covid19". Jurnal Kesehatan Lingkungan Vol 12, No 1si (2020), https://e-journal.unair.ac.id/ JKL/article/view/20770

The Law Number 32 of 2009 on Environmental Protection and Management (n.d.). 